\title{
Mesoporous and adsorptive properties of palm date seed activated carbon prepared via sequential hydrothermal carbonization and sodium hydroxide activation
}

\author{
Md. Azharul Islam ${ }^{\mathrm{a}, \mathrm{b}}$, I.A.W. Tan ${ }^{\mathrm{c}}$, A. Benhouria ${ }^{\mathrm{a}, \mathrm{d}}$, M. Asif ${ }^{\mathrm{e}}$, B.H. Hameed ${ }^{\mathrm{a}, *}$ \\ ${ }^{a}$ School of Chemical Engineering, Engineering Campus, Universiti Sains Malaysia, 14300 Nibong Tebal, Penang, Malaysia \\ ${ }^{\mathrm{b}}$ Forestry and Wood Technology Discipline, Khulna University, Khulna 9208, Bangladesh \\ ${ }^{\mathrm{c}}$ Department of Chemical Engineering and Energy Sustainability, Faculty of Engineering, Universiti Malaysia Sarawak, 94300 Kota Samarahan, Sarawak, Malaysia \\ ${ }^{\mathrm{d}}$ Department of Chemical Engineering, Faculty of Technology, University of Setif 1, Algeria

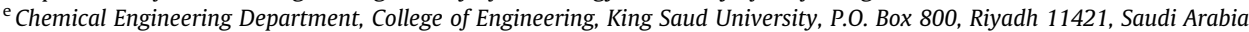

\section{H I G H L I G H T S}

- Mesoporous activated carbon (AC) was prepared from sodium hydroxide activation of hydrochar of palm date seed.

- The BET of AC prepared using 1:3 NaOH impregnation ratio was $1282.49 \mathrm{~m}^{2} / \mathrm{g}$ and 20.73 A average pore width.

- The maximum MB adsorption capacities of $612.1,464.3$, and $410.0 \mathrm{mg} / \mathrm{g}$ were obtained at 30,40 , and $50{ }^{\circ} \mathrm{C}$, respectively.

\section{A R T I C L E I N F O}

\section{Article history:}

Received 8 November 2014

Received in revised form 15 January 2015

Accepted 16 January 2015

Available online 10 February 2015

\section{Keywords:}

Adsorption

Hydrothermal carbonization

Hydrochar

Methylene blue

Palm date seed

\begin{abstract}
A B S T R A C T
Mesoporous activated carbon (AC) was prepared via sodium hydroxide (NaOH) activation of hydrochar from the hydrothermal carbonization (HTC) of palm date seed (PDS). The textural, morphological, and chemical properties of the produced hydrochar AC were investigated. $\mathrm{NaOH}$ activation enhanced the porosity and surface functionality of the hydrochar. Batch equilibration methods were performed to explore the process parameters that affected the adsorption of the prepared AC on methylene blue (MB), including initial concentration, contact time, solution $\mathrm{pH}$ and temperature. The Freundlich isotherm model better depicted the equilibrium data compared with the Langmuir isotherm model. Temperature was found to negatively affect the adsorption capacity of the prepared AC, which exhibited 612.1, 464.3 and $410.0 \mathrm{mg} / \mathrm{g}$ maximum MB adsorption capacities at 30,40 and $50{ }^{\circ} \mathrm{C}$, respectively. The pseudo-second order kinetic model best described the kinetic data. HTC and $\mathrm{NaOH}$ activation was proven to be an effective method in preparing highly porous AC from PDS, with good potential for cationic dye removal from liquid phase.
\end{abstract}

(c) 2015 Elsevier B.V. All rights reserved.

\section{Introduction}

Activated carbon (AC) is conventionally synthesized using char from the pyrolysis of organic material, which then undergoes a physical or chemical activation process at a high temperature. A potential alternative method of converting biomass into char in a more energy-efficient process is via hydrothermal carbonization (HTC). HTC is a thermochemical synthesis method used to produce functional carbon materials from pure carbohydrates or lignocellulosic biomass with tunable chemical structures [1]. HTC is a thermal conversion process at a comparatively low temperature and

\footnotetext{
* Corresponding author. Tel.: +60 45996422; fax: +60 45941013.

E-mail address: chbassim@usm.my (B.H. Hameed).
}

has been proven to be environmentally favorable for the conversion of various precursors into value-added products [2-5]. Three products are formed from HTC, namely, a solid hydrochar, an aqueous soluble liquid, and a gas that mainly consists of carbon dioxide. HTC is more energy-efficient than pyrolysis mainly because milder thermal conditions are used in HTC. In addition, HTC is exothermic; thus, wet materials can be used directly without any drying process [6,7].

A number of studies have been reported recently on HTC of various biomass materials. However, most research has been mainly focused on the production of bio-oil, with only few studies investigating the applications of hydrothermal carbon or hydrochar. Falco et al. [1] investigated the influences of biomass precursor (i.e., D-glucose, cellulose, rye straw) and HTC temperature on porosity 